\title{
The McCoy Society's Expedition to Lady Julia Percy Island
}

\author{
By Prof. Frederic Wood Jones, F.R.S.
}

$\mathrm{T}$ HE complete ecological survey of Lady Julia Percy Island was the first enterprise undertaken (in January 1936) by the McCoy Society for Field Investigation and Research. The McCoy Society was founded and organized by students of the University of Melbourne during 1935; and Lady Julia Percy Island lies off the coast of western Victoria $\left(38^{\circ} 24^{\prime} \mathrm{S} ., 142^{\circ}\right.$ E.). The island is separated from the mainland by a channel some five miles wide, and with as much as twenty

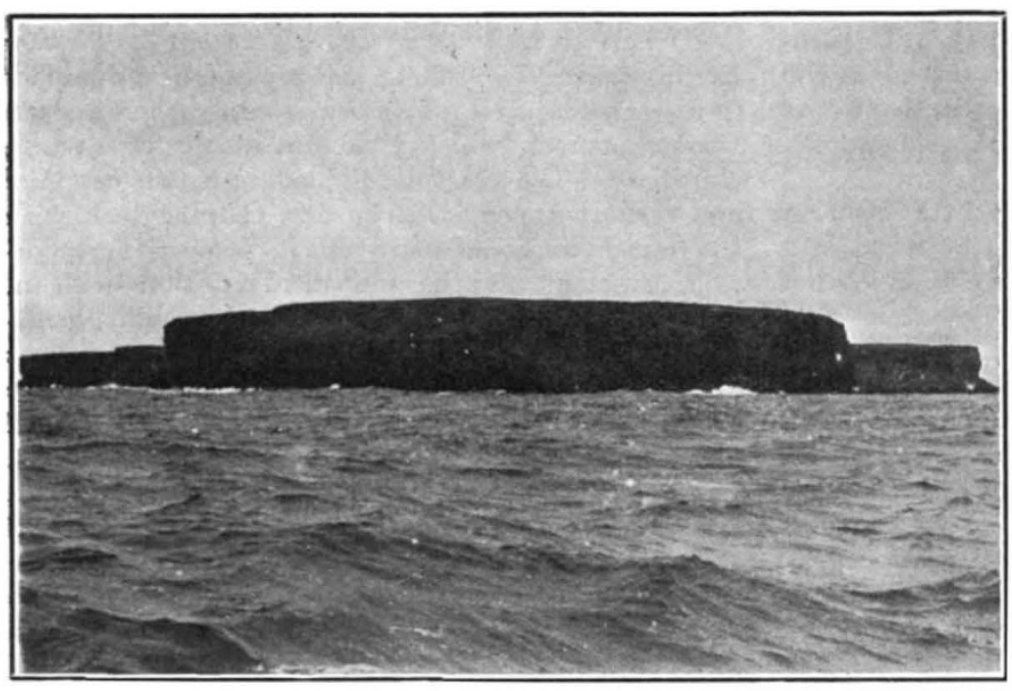

Photo: McCoy Society.

Fig. 1. Lady Julia Percy Island, an isolated volcanic pile lying off the south coast of Victoria. growth more majestic than bracken fern and thistles. The whole plateau is, at present, a windswept area, clothed only by vegetation knee-high at the best, and at the worst, by loose volcanic soil or bare rock. This denudation of forest cover is due to human interference, for pigs were at one time turned down on the island, rabbits were liberated and are still living in their thousands, and sealers, fishermen and guano workers have cut down and burned the stunted and wind-blown trees that formerly covered the island.

Barren, inhospitable and forbidding though the island now appears, it proved to be a place of the most absorbing interest. The Bass Straits, St. Vincent's and Spencer's Gulfs, and the Great Australian Bight-the whole of the southern shores of Victoria and South Australia are dotted with islands, and I have visited more than thirty of them. But Lady Julia Percy Island, off Port Fairy, in Victoria, is different from all these. It is a pure volcanic island up. risen in the sea, and it has never formed a part of the continental mass of Australia, as have all the other offshore islands.

The whole of the flora and fauna of the island tell the same story as that which was unravelled by the geologists of the party. No land molluses live on the island, though even the most inconsiderable of the islands of the Bight, and of Bass Straits, support a flourishing land-shell fauna. No slugs were present, and no amphibia. The only earthworm was not an Australian species, but was one introduced from Europe-an eloquent testimony to the reality of human interference in the dispersal of animal forms. There were no snakes, and the only reptile was a lizard which has an aptitude for being dispersed on every tiny frag. ment of land that lies off the Australian coast. No mammals live on the island plateau save the swarm of introduced rabbits, and the history of their advent is well attested. The only other mammals are the sea lions that resort to the island to breed, to raise their pups, to play, squabble and indulge in aquatic sports, and generally to 
have a wonderful time of fooling about that renders them the most engaging of animals for the casual observer-and the most lovable to the real student of Nature. It is a noteworthy fact that the sea lion of Lady Julia Percy Island differs profoundly, both in behaviour and in anatomical characters, from the species that inhabits the islands of the Great Australian Bight. This sea lion is a resident and local species, just as is the sea lion of the islands to the west, and it is much to be desired that local and uninformed legislation will never be directed towards the slaughter of these animals, the distribution of which is so restricted and the economy of which is, at present, so little understood.

The birds inhabiting the island are of two kinds, the land birds resident and breeding in the island, and the truly marine species that breed upon the plateau or among the rock boulders. In addition to these breeding species there are the visitors, both land and marine.

The resident and breeding species of land birds are of no especial interest. Native swallows, pipits, chats and redcapped dottrel breed in their accustomed sites upon the island, but only the pipits and the chats are numerous. The fine native swamp harrier is the dominant bird, and it breeds among the bracken ferns upon the open island plateau. On our arrival, these birds were so tame that it was possible to pick up the fully fledged young birds from their nests among the bracken; but, although they were not molested, they very soon learned all the wariness of their kind. They are the most conspicuous birds of the island and, at almost any time of the day, half a dozen or so could be seen floating above the plateau on the watch for young rabbits, penguins and mutton birds. Even the kestrels and the peregrines, which had apparently nested on the rock ledges of the cliffs, took a very minor part in policing the plateau. Introduced starlings and sparrows have reached the island, but they are inconspicuous and timid, and, for the most part, have their home in the volcanic cliffs and find their food upon the seal beaches.

Of the true sea birds, the Bass Straits mutton birds or short-tailed (or slender-billed) shearwaters (Puffinus tenuirostris) breed in large numbers in burrows tunnelled into the soft volcanic earth of the island plateau. The whale bird, ice bird or prion (Prion turtur) visits the island to lay its egg in the cavities beneath the vast basaltic boulders that strew the shore line, and the talus slopes of those parts of the island where the cliffs do not rise sheer from the water's edge. The shearwater and probably the prion are seasonal breeding visitors, but almost certainly the little diving petrel (Pelecanoides urinatrix) is a resident bird, breeding on the island and returning to it at dusk all the year round. The diving petrel is one of the most attractive of sea birds, a sturdy, manly, independent little fellow, with the most beautiful turquoise blue legs and feet and shining black and white plumage. He comes to the island only when the evening dusk has settled down, and as he

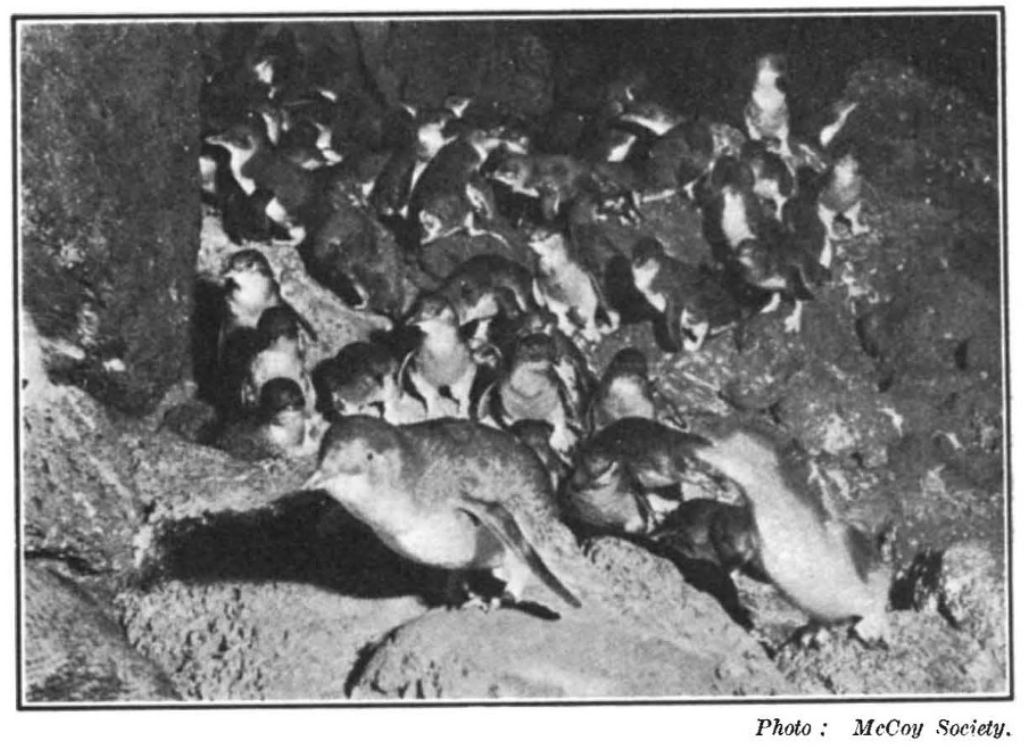

ening arrival of the penguins. The start of the long climb from the sea to the top of the island, taken by flashlight.

comes he makes a little noise like a new-born puppy seeking its mother. From beneath some great boulder there comes the same little sound in answer, and soon, after flitting around like a bat in the dusk, he creeps into some chink, and a duet of little puppy-like love notes comes forth.

The prion is a ghost. A fluttering thing of pale grey-blue and white, a delicate wraith of a bird that comes moth-like into the beam of an electric torch and falls confused among the boulders-as it does at every lighthouse on the islands around the coasts of Victoria and Tasmania.

The Bass Straits shearwaters are birds of mystery. Anyone who has watched their evening arrival at a breeding island, seen their wheeling, watched them, as myriads of boomerangs, hurtling in the air, and followed their flutterings as they quarter the ground seeking their breeding burrows, has witnessed one of the most remarkable perfections of avian flight. 
Then everywhere on the island are the penguins (Eudyptula minor). These little blue and white birds are among the most engaging of all the penguins, despite the fact that all their island activities are nocturnal. In solemn thousands they come ashore from the surf, and always at the same place, and in a sudden rush, every evening.

Every evening the whole company marches and hops up the same well-marked pathway to the island plateau and, at the plateau, disperses along numerous tracks to the breeding burrows. Every step of the way, every jump, every turn, is performed by every individual in the whole great army in exactly the same manner, and with the utmost solemnity. Every bird that, after the whole long journey, arrives at its home, finds two fluffy chicks awaiting it at the mouth of the burrow and regarding it with solemn expectancy. The little blue penguin is attractive beyond all birds in its serious and ordered ways of life, and in its queer sturdy independence that is combined with a most remarkable communal spirit. It is a strange thing that all these birds coming to the island at nightfall should forgather in the surf until their numbers are complete, and then, making a concerted rush through the breakers to the landing rock, start their long climb together (Fig. 2). For this coming and going is their time of peril, and a visit to any island upon which penguins breed tells its own tale. Penguin carcases, killed by harriers, peregrines and seals, strew the pathway from the surf to the breeding places; and around the rock holes or the burrows in which they breed are downy chicks ripped open by hawks or gulls. On Lady Julia Percy Island they did not have to run the gauntlet of gulls, for, strangely enough, these birds were not present on the island; but despite this, their mortality was very high.

During the hours of daylight, the island was a comparatively quiet place. Always there were the farmyard noises of the sea lions, for every sound, from the bleating of the lamb to the snarling of dogs and the lowing of oxen, came perpetually from the seal beaches. But when dusk came on there were added the indescribable groaning, mewing and caterwauling tumult from the mutton birds; the noise, rising from human snoring almost to donkey braying, of the penguins, and the newborn puppy sounds from the diving petrels and the prions. But despite all this, and the scarcity of fresh water, the members of the McCoy Society spent six happy weeks camped upon this volcanic island. They examined and collected everything, from soil bacteria to sea lions, and endeavoured to link the whole together in one complete ecological survey.

\title{
Terminology in Physics
}

\author{
By Prof. C. G. Darwin, F.R.S.
}

$\mathrm{T}$ HERE has for some time existed an international committee, the 'S.U.N.', charged with the duty among other subjects of standardizing the nomenclature of physical quantities. So far as concerns such things as the names of units and their symbols it has proved effective. There has perhaps been a tendency for some of the members to point out that the majority were marching out of step; but in view of the very different approaches of different schools of thought, a certain latitude is perhaps permissible in the meaning and symbol of such a thing as free energy. This side of the question of nomenclature is adequately cared for, and is not the subject of the present article. Here it is proposed to consider certain obvious deficiencies and nonconformities in descriptive technical terms as they have arisen during the last decade or so in both English and American writings on atomic physics. It is not to be expected, perhaps not even to be desired, that any exact uniformity should be reached, but there are a number of cases where there is complete anarchy, and it is the aim of the present review to examine what principles should guide us in giving names to things, and possibly in a few examples to suggest appropriate solutions which may appeal to some of those who have not a conscientious preference for anarchy.

One of the greatest difficulties in the naming of physical ideas lies in the difficulty of translating a name out of one language into another. Consider, for example, the energy that remains in a body at the absolute zero of temperature. This idea was chiefly developed in German writings, and the quantity, following the polysynthetic spirit of the language, was called Nullpunktsenergie -name and definition in a single mouthful. Unfortunately, those who are charged with the literary side of education in England seem to hold that the best way to teach the writing of English is by 